\title{
PERAN DAN FUNGSI PEMERINTAHAN GOOD GOVERNANCE DALAM MENDORONG PERTUMBUHAN EKONOMI DI PROVINSI BALI
}

\author{
I Gde Surya Kurniawan \\ Fakultas Ilmu Sosial dan Ilmu Politik Universitas Mahendradatta Denpasar
}

\begin{abstract}
Abstrak - Bali dalam perkembangannya tidak terlepas dari prinsip-prinsip yang dipegang teguh oleh masyarakat seperti konsep Tri Hita Karana-hubungan manusia dengan manusia, hubungan manusia dengan alam dan hubungan manusia dengan Tuhan. Karena itu, mengikutsertakan seluruh komponen masyarakat Bali (inclusive growth) dalam memacu pertumbuhan ekonomi adalah suatu keharusan. Pertumbuhan ekonomi yang terjadi mesti tersebar ke seluruh kabupaten/kota di Bali terutama daerah dengan tingkat kemiskinan yang tinggi sebagai upaya mengurangi tingkat kesenjangan antar daerah (kabupaten/kota), mengingat sejauh ini perekonomian Bali masih bertumpu pada ekonomi tersier (services sector), dan ada kecenderungan pembangunan lebih terkonsentrasi pada wilayah Bali bagian selatan meliputi Denpasar, Badung, Gianyar dan Tabanan (Sarbagita).
\end{abstract}

Berdasarkan atas hasil penelitian diperoleh kesimpulan, antara lain: Pelaksanaan good governance di Provinsi Bali semakin baik, ditunjukkan dengan pencapaian nilai LAKIP dan LKPD Provinsi Bali, kabupaten/kota se-Bali yang semakin meningkat dari tahun ke tahun. Hal tersebut berpengaruh terhadap kondisi perekonomian di Provinsi Bali dari tahun ke tahun telah mengalami perkembangan yang baik, hal tersebut dapat diamati dalam komponen pertumbuhan ekonomi yang semakin tinggi, jumlah penduduk miskin dan tingkat ketimpangan semakin berkurang. Pelaksanaan good governance di Pemerintah Kabupaten di Wilayah Provinsi Bali mempunyai peranan yang sangat penting dalam proses peningkatan pertumbuhan ekonomi yang bermuara kepada kesejahteraan masyarakat.

Sejumlah saran yang dapat disampaikan berkaitan dengan pembahasan yang telah disampaikan, adalah sebagai berikut: Bahwa good governance diperlukan untuk mendukung penerapan kebijakan-kebijakan pemerintah yang berorientasi kepada peningkatan indikator pertumbuhan ekonomi dan kesejahteraan masyarakat agar lebih efektif dan dapat berdampak secara komprehensif sesuai dengan tujuannya masing-masing. Pemerintah Provinsi sebagai wakil pemerintah pusat di daerah kiranya dapat memberikan stimulus kepada pemerintah Kabupaten/Kota yang telah menerapkan good governance dalam pelaksanaan pemerintahan dengan baik, sehingga diharapkan dapat semakin mendorong peningkatan pertumbuhan ekonomi dan kesejahteraan masyarakat. Pemerintah Daerah di Lingkungan Provinsi Bali kiranya dapat semakin meningkatkan inovasinya dalam menerapkan good governance dalam pelaksanaan tugas pokok dan fungsinya.

Kata kunci: good governance, pertumbuhan ekonomi

Abstract - Bali in its development cannot be separated from principles that are firmly held by society such as the Tri Hita Karana concept - the human-human relationship, the human-nature relationship and the human-God relationship. Therefore, including all components of Balinese society (inclusive growth) in spurring economic growth is a must. The economic growth that occurs must be spread throughout all districts / cities in Bali, especially areas with high poverty rates as an effort to reduce the level of disparity between regions (districts / cities), considering that so far the Balinese economy still relies on the tertiary economy (services sector), and there are The development trend is 
more concentrated in the southern part of Bali, including Denpasar, Badung, Gianyar and Tabanan (Sarbagita).

Based on the research results, it can be concluded that, among others: The implementation of good governance in Bali Province is getting better, as indicated by the achievement of LAKIP and LKPD scores for Bali Province, regencies / cities in Bali which are increasing from year to year. This has affected the economic conditions in Bali Province from year to year, which has experienced good development, this can be observed in the components of higher economic growth, the number of poor people and the decreasing level of inequality. The implementation of good governance in the Regency Government in the Province of Bali has a very important role in the process of increasing economic growth which leads to the welfare of the community.

A number of suggestions that can be conveyed in relation to the discussions that have been submitted are as follows: That good governance is needed to support the implementation of government policies that are oriented towards increasing indicators of economic growth and community welfare so that they are more effective and can have a comprehensive impact according to their respective objectives. respectively. The Provincial Government as the representative of the central government in the regions can provide a stimulus to Regency / City governments that have implemented good governance in the implementation of good governance, so that it is expected to further encourage an increase in economic growth and community welfare. Local governments in the Bali Province can further increase their innovation in implementing good governance in the implementation of their main duties and functions.

Keywords: good governance, economic growth

\section{BAB I \\ PENDAHULUAN}

\section{A. Latar Belakang Masalah}

Bali dalam perkembangannya tidak terlepas dari prinsip-prinsip yang dipegang teguh oleh masyarakat seperti konsep Tri Hita Karana-hubungan manusia dengan manusia, hubungan manusia dengan alam dan hubungan manusia dengan Tuhan. Terkait dengan hal demikian maka jumlah penduduk yang ideal secara normatif adalah yang memenuhi aspek-aspek kesejahteraan individu, keseimbangan dengan lingkungan, kekayaan spiritual. Secara realistis hal itu sulit dicapai, namun ketiga aspek tersebut mampunyai hubungan sebab akibat dengan pola perubahan penduduk di suatu wilayah.

Karena itu, mengikutsertakan seluruh komponen masyarakat Bali (inclusive growth) dalam memacu pertumbuhan ekonomi adalah suatu keharusan. Pertumbuhan ekonomi yang terjadi mesti tersebar ke seluruh kabupaten/kota di Bali terutama daerah dengan tingkat kemiskinan yang tinggi sebagai upaya mengurangi tingkat kesenjangan antar daerah (kabupaten/ kota), mengingat sejauh ini perekonomian Bali masih bertumpu pada ekonomi tersier (services sector), dan ada kecenderungan pembangunan lebih terkonsentrasi pada wilayah Bali bagian selatan meliputi Denpasar, Badung, Gianyar dan Tabanan (Sarbagita).

Sebagaimana telah disampaikan, bahwa pendapatan riil perkapita merupakan salah satu pendorong pertumbuhan ekonomi yang berkualitas. Produk Domestik Regional Bruto (PDRB) merupakan gambaran mengenai keadaan pertumbuhan perekonomian suatu daerah pada suatu waktu, pertumbuhan ekonomi diperoleh dari ratio PDRB perkapita dari tahun sebelumnya (Sukirno, 2007). Demikian halnya perkembangan perekonomian kabupaten/kota di Provinsi Bali dapat ditunjukkan dengan melihat perkembangan PDRB-nya, untuk lengkapnya rincian PDRB atas dasar harga konstan dapat dilihat pada Grafik 1.1. 
Grafik 1.1

PDRB Kabupaten/Kota di Provinsi Bali Menurut Harga Konstan

Tahun 2009 - 2014

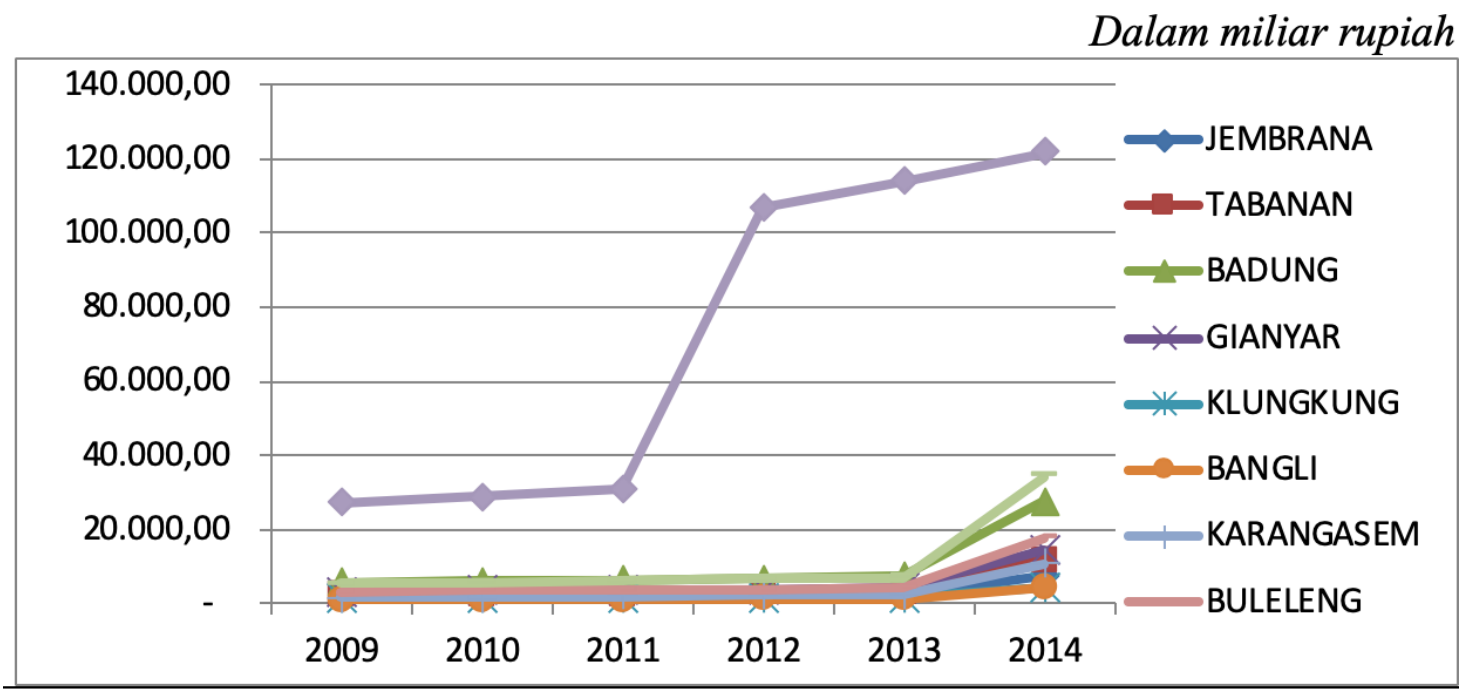

Sumber : BPS.Provinsi Bali, 2015

Sesuai dengan grafik 1.1 diatas, bahwa kenaikan PDRB Kabupaten/kota mulai terjadi pada tahun 2013 dengan tingkat kenaikan yang relatif tinggi, sedangkan untuk tingkat provinsi kenaikan relatif tinggi mulai terjadi pada tahun 2011. Total nilai tambah yang tercipta (PDRB nominal/atas dasar harga berlaku) di Bali pada tahun 2015 telah mencapai $\mathrm{Rp} 177,17$ trilyun atau naik 13,29 persen dari tahun sebelumnya yang senilai Rp 156,38 trilyun.

\section{Gambaran Umum Pertumbuhan Ekonomi Provinsi Bali8}

Pertumbuhan ekonomi merupakan perkembangan kegiatan dalam perekonomian yang menyebabkan barang dan jasa yang diproduksi dalam masyarakat bertambah sehingga akan meningkatkan kemakmuran masyarakat (Sukirno,1994). Menurut Boediono, pertumbuhan ekonomi merupakan proses kenaikan output per kapita dalam jangka panjang. Sedangkan menurut Lincolin (1997), pertumbuhan ekonomi diartikan sebagai kenaikan GDP/GNP tanpa memandang apakah kenaikan tersebut lebih besar atau lebih kecil dari tingkat pertumbuhan penduduk, dan apakah terjadi perubahan struktur ekonomi atau tidak.

Berdasarkan Grafik 1.2 dapat diket- ahui bahwa pertumbuhan perekonomi- an Provinsi Bali dalam kurun waktu 2010 hingga 2014 cenderung mengala- mi peningkatan walaupun pada tahun 2010 perekonomian Bali mengalami penurunan dampak terjadinya krisis glob- al. Setelah krisis global tersebut berlalu secara perlahan pertumbuhan ekonomi Bali mengalami trend positif dan bera- da pada kisaran diatas 6 persen, capaian pertumbuhan tertinggi dicapai pada tahun 2012 yaitu sebasar 6,96 persen.

Dalam hal Provinsi Bali, strukturekonomi yang dibangun terbilang cukup berbeda jika dibandingkan dengan provinsi lainnya di Indonesia. Industri pariwisata dalam arti luas yang kini menjadi penggerak utama (leading sector), telah mendorong terjadinya perubahan struktur ekonomi dari primer ke tersier. Pada tahun 2015, dominasi sektor tersier tampak dengan jelas. Lapangan Usaha tersier memegang peran sebesar 68,17 persen. Sementara lapangan usaha premier dan sekunder masing masing memberi kontribusi sebesar 16,02 persen dan 15,81 persen. 


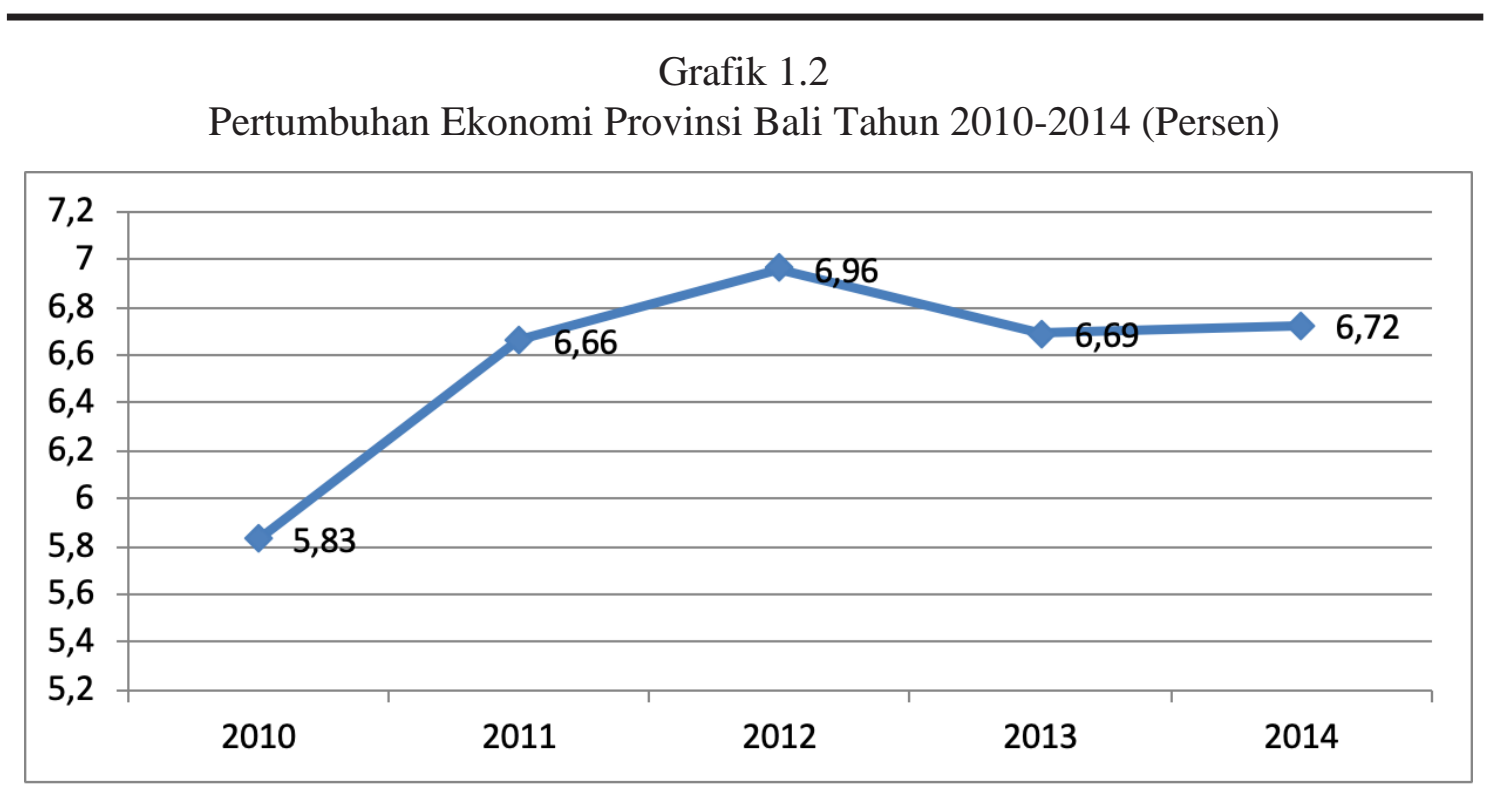

Sumber: BPS, Statistik Indonesia, 2015

\section{Gambaran Umum Good Gov- ernance pada kabupaten/kota di Provinsi Bali}

Penerapan prinsip-prinsip good governance sangat penting dalam pelaksanaan kegiatan pemerintah untuk mewujudkan kesejahteraan dan pemerataan, hal ini disebabkan karena tujuan dilaksanakan pembangunan salah satunya adalah dengan mewujudkan perubahan dalam birokrasi yang memiliki komitmen terhadap kesejahteraan rakyat (Simatupang, 2007). Paradigma governance ini merupakan suatu pergeseran dari paradigma government yang menekankan pada kolaborasi dalam kesetaraan dan keseimbangan antara pemerintah, sektor swasta, dan masyarakat madani (Pandji Santosa, 2008).

Tuntutan Era Globalisasi dan keterbukaan mengharuskan adanya kepemerintahan yang baik, perwujudan good governance dalam sistem pemerintahan Indonesia diantaranya adalah melalui penilaian terhadap Laporan Kinerja Instansi Pemerintah (LAKIP) dan Laporan Keuangan Pemerintah Daerah (LKPD) yang mempunyai 4 (empat) jenis opini. Kriteria yang dijadikan dasar dalam pemberian opini kepada pemerintah daerah adalah: Kesesuaian dengan Standar Akuntansi Pemerintahan (SAP); Kecukupan pengungkapan;Kepatuhan ter- hadap peraturan perundang-undagan; Efektivitas sistem pengendalian internal. Sebagai perbandingan dapat disampaikan perkembangan nilai LAKIP Kabupaten Badung dari tahun 2008 sampai dengan 2014, sebagaimana dijelaskan pada Grafik 1.3.

Opini LKPD pemerintah kabupaten/kota berdasarkan atas indikator kesesuaian dengan standar akuntansi pemerintahan, kecukupan pengungkapan, kepatuhan terhadap peraturan perundang-undangan, efektivitas sistem pengendalian internal yang merupakan perwujudan dari good governance dan clean government. Opini tersebut yaitu: opini Wajar Tanpa Pengecualian (WTP), opini Wajar Dengan Pengecualian (WDP). Opini Tidak Wajar (TW), dan Tidak Memberi Pendapat (TMP). Sedangkan penilaian dari BPK tersebut, pelaksanaan Good Governance dapat dilihat pada penerapan Sistem Akuntabilitas Kinerja Instansi Pemerintah (SAKIP) mengacu kepada Peraturan Pemerintah Nomor 8 tahun 2008 tentang tahapan, tata cara penyusunan, pengendalian, dan evaluasi pelaksanaan rencana pembangunan daerah tersebut telah mengubah sistematika penyusunan dokumen perencanaan. 
Grafik 1.3

Nilai LAKIP Pemerintah Kabupaten Badung Tahun 2018 - 2014

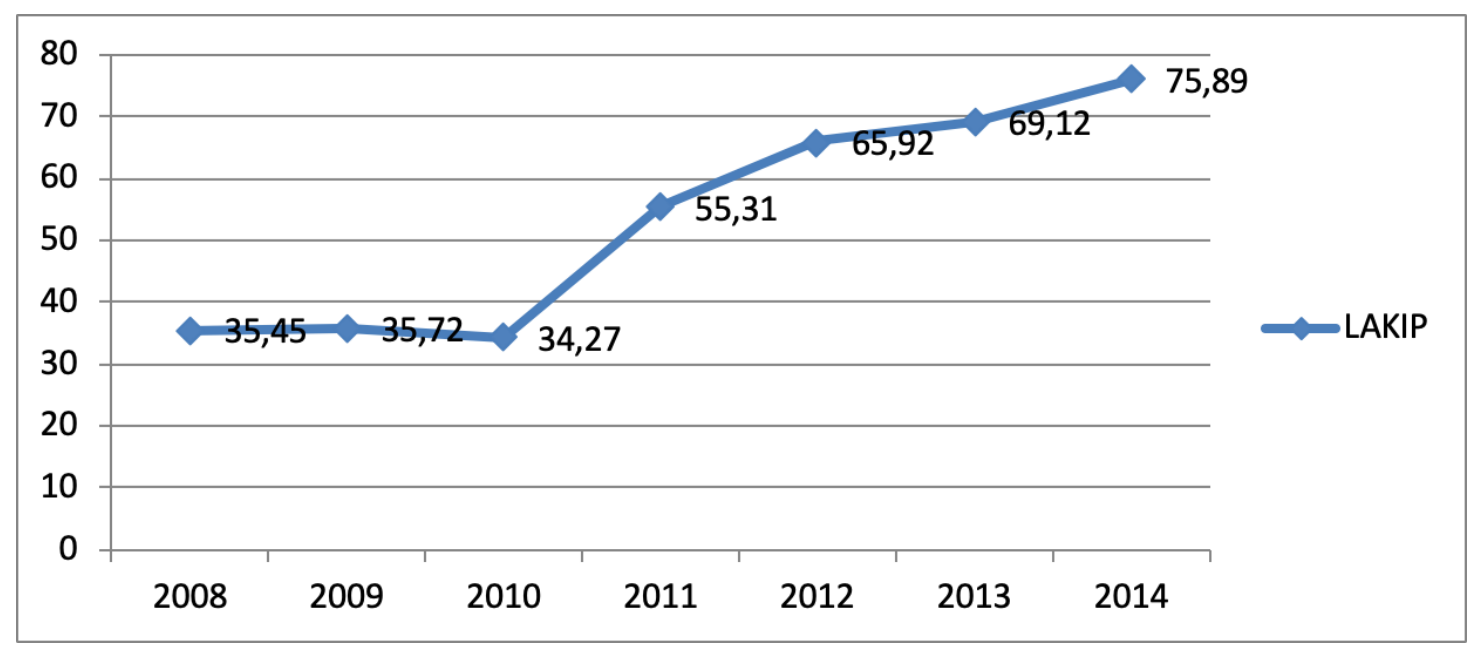

Tabel 1.1

Perkembangan Opini BPK-RI Terhadap Provinsi/Kabupaten/Kota di Provinsi Bali Tahun $2009-2014$

\begin{tabular}{|c|l|c|c|c|c|c|c|}
\hline NO & \multicolumn{3}{|c|}{ LKPD } & \multicolumn{5}{|c|}{ OPINI } \\
\cline { 3 - 8 } & & $\mathbf{2 0 0 9}$ & $\mathbf{2 0 1 0}$ & $\mathbf{2 0 1 1}$ & $\mathbf{2 0 1 2}$ & $\mathbf{2 0 1 3}$ & $\mathbf{2 0 1 4}$ \\
\hline 1. & Jembrana & TW & TW & WDP & WDP & WDP & WTP \\
2. & Tabanan & WDP & WDP & WDP & TMP & WDP & WTP \\
3. & Badung & WDP & WDP & WTP & WTP & TW & WTP \\
4. & Gianyar & WDP & WDP & WDP & WDP & WDP & WTP \\
5. & Klungkung & WDP & WDP & WDP & WDP & WDP & WDP \\
6. & Bangli & WDP & WDP & WDP & WDP & TMP & WDP \\
7. & Karangasem & WDP & TMP & WDP & WDP & WDP & WDP \\
8. & Buleleng & WDP & TMP & WDP & WDP & WDP & WTP \\
9. & Denpasar & WDP & WDP & WDP & WTP & WTP & WTP \\
10. & Prov.Bali & WDP & WDP & WDP & WDP & WTP & WTP \\
\hline
\end{tabular}

Sumber: BPK- RI Perwakilan Provinsi Bali, 2015

Pemberian opini tersebut berdasarkan atas indikator kesesuaian dengan standar akuntansi pemerintahan, kecukupan pengungkapan, kepatuhan terhadap peraturan perundang-undangan, efektivitas sistem pengendalian internal yang merupakan perwujudan dari good governance dan clean government. Opini tersebut yaitu: opini Wajar Tanpa Pengecualian (WTP), opini Wajar Dengan Pengecualian(WDP). Opini Tidak Wajar (TW), dan Tidak Memberi Pendapat (TMP). Selain penilaian dari BPK tersebut, pelaksanaan Good Governance dapat dilihat pada penerapan Sistem Akuntabilitas Kinerja Instansi Pemerin- tah (SAKIP) mengacu kepada Peraturan Pemerintah Nomor 8 tahun 2008 tentang tahapan, tata cara penyusunan, pengendalian, dan evaluasi pelaksanaan rencana pembangunan daerah tersebut telah mengubah sistematika penyusunan dokumen perencanaan.

Pelaksanaan kebijakan tata kepemerintahan yang baik pada Pemerintah Provinsi, Kabupaten/Kota di Bali telah dicantumkan pada arah kebijakan pemerintah, seperti contohnya telah tercantum dalam arah kebijakan Pemerintah Provinsi Bali pada point 5 yaitu "Mengintensifkan pelaksanaan tata kelola kepemerintahan yang 
baik". Adapun pelaksanaan secara garis besar telah dicantumkan pada Prioritas Reformasi Birokrasi dan Tata Kelola.

\section{B. Identifikasi Masalah}

Sesuai dengan latar belakang masalah tersebut diatas, maka identifikasi masalah yang dinyatakan dalam penelitian adalah:

1. Pertumbuhan ekonomi di Provinsi Bali dalam kurun waktu tahun 2010-2014 yang semakin meningkat.

2. Tingkat pelaksanaan GoodGovernance dalam pemerintahan dalam kurun waktu tahun 2010-2014 yang semakin meningkat.

3. Tantangan yang dihadapi oleh pemerintah daerah yang ada di Provinsi Bali dalam penerapan Good Governance.

Masih terdapat banyak faktor yang perlu diidentifikasi, walaupun demikian faktor-faktor yang telah disebutkan dalam identifikasi masalah diatas telah memberikan gambaran yang memadai.

\section{Rumusan Masalah}

Penelitian ini mencoba untuk menjelaskan pengaruh penerapan Good Governance dalam lingkup Pemerintah Daerah di Lingkungan Provinsi Bali terhadap tingkat pertumbuhan ekonomi dan juga kesejahteraan masyarakat di Provinsi Bali. Perumusan masalah dalam penelitian ini adalah sebagai berikut:

1. Bagaimanakah pengaruh penerapan Good Governance terhadap pertumbuhan ekonomi di Provinsi Bali.

2. Bagaimanakah pengaruh penerapan Good Governance terhadap kesejahteraan masyarakat di Provinsi Bali.

\section{Tujuan Penelitian}

Penelitian ini adalah untuk menambah khazanah perkembangan ilmu sosial politik dihubungkan dengan ilmu ekonomi pembangunan, yaitu dengan:

1. Mengkaji hubungan antara penerapan Good Governance di Pemerintah Daerah di Lingkungan Provinsi Bali terhadap pertumbuhan ekonomi di Provinsi Bali;

2. Mengkaji hubungan antara penerapan Good Governance di Pemerintah Daerah di Lingkungan Provinsi Bali terhadap kesejahteraan masyarakat di Provinsi Bali.

\section{E. Manfaat Penelitian \\ a. Secara Teoritik}

Hasil penelitian ini diharapkan dapat bermanfaat untuk:

1. Menjelaskan keterkaitan antara penerapan Good Governance pada Pemerintah Daerah di wilayah Provinsi Bali terhadap tingkat pertumbuhan ekonomi di Provinsi Bali.

2. Menjelaskan keterkaitan antara penerapan Good Governance pada Pemerintah Daerah di wilayah Provinsi Bali terhadap tingkat kesejahteraan masyarakat di Provinsi Bali

\section{b. Secara Praktis}

Bagi pemerintah (policy maker), sebagai bahan pertimbangan dalam menentukan kebijakan yang akan diambil, khususnya kebijakan untuk mendorong penerapan aspek-aspek good governance yang baik dalam setiap pelaksanaan tugas pokok dan fungsi instansi pemerintah sehingga mampu mendorong pertumbuhan ekonomi dan kesejahteraan masyarakat.

\section{BAB II \\ PEMERINTAHAN GOOD GOVERN- ANCE}

DAN PERTUMBUHAN EKONOMI

\section{Fungsi - Fungsi Pemerintah}

Pemerintah tidaklah diadakan untuk melayani diri sendiri, tetapi untuk melayani masyarakat, menciptakan kondisi yang memungkinkan setiap anggota mengembangkan kemampuan dan kreatifitasnya demi mencapai kemajuan bersama (Rasyid, 2000). Osborne dan Gaebler (terjemahan Rosyid, 2000) bahkan menyatakan bahwa pemerintah yang demokratis lahir untuk melayani warganya dan karena itulah tugas pemerintah adalah mencari cara untuk menyenangkan warganya.

Dengan demikian lahirnya pemerintahan memberikan pemahaman bahwa kehadiran suatu pemerintahan merupakan manifestasi dari kehendak masyarakat yang bertujuan untuk berbuat baik bagi kepentingan masyarakat, bahkan Van Poelje (Hamdi, 1999) menegaskan bahwa pemerintahan dapat dipandang sebagai suatu ilmu yaitu yang mengajarkan bagaimana cara terbaik dalam mengarahkan dan memimpin pelayanan umum. Ndraha (2000) mengatakan bahwa pemer- 
intah memegang pertanggungjawaban atas kepentingan rakyat. Lebih lanjut Ndraha juga mengatakan bahwa pemerintah adalah semua beban yang memproduksi, mendistribusikan, atau menjual alat pemenuhan kebutuhan masyarakat berbentuk jasa publik dan layanan civil. Sejalan dengan itu, Kaufman (dalam Thoha, 1995) menyebutkan bahwa:

Tugas pemerintahan adalah untuk melayani dan mengatur masyarakat. Kemudian dijelaskan lebih lanjut bahwa tugas pelayanan lebih menekankan upaya mendahulukan kepentingan umum, mempermudah urusan publik dan memberikan kepuasan kepada publik, sedangkan tugas mengatur lebih menekankan kekuasaan power yang melekat pada posisi jabatan birokrasi.

Rasyid (2000), menyatakan bahwa tugas-tugas pokok pemerintah dapat diringkas menjadi 3 (tiga) fungsi hakiki yaitu: pelayanan (service), pemberdayaan (empowerment), dan pembangunan (development). Pelayanan akan membuahkan keadilan dalam masyarakat, pemberdayaan akan mendorong kemandirian masyarakat, dan pembangunan akan menciptakan kemakmuran dalam masyarakat.

Ndraha (2001), fungsi pemerintahan tersebut kemudian diringkus menjadi 2 (dua) macam fungsi, yaitu: Pertama, pemerintah mempunyai fungsi primer atau fungsi pelayanan (service), sebagai provider jasa publik yang baik diprivatisasikan dan layanan civil termasuk layanan birokrasi. Kedua, pemerintah mempunyai fungsi sekunder atau fungsi pemberdayaan (empowerment), sebagai penyelenggara pembangunan dan melakukan program pemberdayaan.

Hal demikian menunjukkan bahwa peran dikatakan telah dilaksanakan apabila seseorang dengan kedudukan atau status tertentu telah melaksanakan kewajiban-kewajibannya. Peran dapat dibagi dalam tiga cakupan, yaitu (Soekanto, 2004): Peranan meliputi norma-norma yang dihubungkan dengan posisi atau tempat seseorang dalam masyarakat, peranan dalam arti merupakan rangkaian-rangkaian peraturan yang membimbing seseorang dalam kehidupan kemasyarakatan. Peranan adalah suatu konsep tentang apa yang dilakukan oleh individu dalam masyarakat sebagai organisasi. Peranan juga dapat dikatakan sebagai perilaku individu yang penting bagi struktur sosial masyarakat.

Fungsi pemerintah menurut Richard A. Musgrave dibedakan menjadi tiga fungsi dan tujuan kebijakan anggaran belanja pemerintah, yaitu:

1. Fungsi Alokasi (Allocation Branch) Yaitu fungsi pemerintah untuk menyediakan pemenuhan untuk kebutuhan Publik (public needs).

2. Fungsi Distribusi (Distribution Branch) Yaitu fungsi yang dilandasi dengan mempertimbangkan pengaruh sosial ekonomis; yaitu pertimbangan tentang kekayaan dan distribusi pendapatan, kesempatan memperoleh pendidikan, mobilitas sosial, struktur pasar. Macam-ragam warga negara dengan berbagai bakatnya termasuk tugas fungsi tersebut.

3. Fungsi Stabilisasi (Stabilizaton Branch) Yaitu fungsi menyangkut usaha untuk mempertahankan kestabilan dan kebijaksanaan- kebijaksanaan yang ada. Disamping itu, fungsi ini bertujuan untuk mempertahankan kestabilan perekonornian (stabilisator perekonomian) (Guritno, 2000).

Fungsi pemerintah jelas dijelaskan pada konsep negara kesejahteraan, konsep tersebut menekankan kepada peran pemerintah yang responsif dalam mengorganisasikan dan mengelola perekonomian sehingga mampu melaksanakan tanggungjawabnya guna menjamin ketersediaan pelayanan kesejahteraan dasar dalam tingkat tertentu bagi warganya (Andersen, 1997). Todaro (1997) menyebutkan bahwa pemerintah harus diakui dan dipercaya untuk memikul peranan lebih besar dan yang lebih menentukan di dalam upaya pengelolaan perekonomian daerah/nasional. Pembangunan ekonomi tidak dapat dilepaskan dari peranan pemerintah dalam menciptakan suatu kondisi yang dapat mendukung elemen-elemen dalam pertumbuhan ekonomi dan kesejahteraan yang dapat dicapai suatu daerah. Beberapa upaya pemerintah tersebut ditempuh antara lain dengan berbagai regulasi, nasionalisasi perusahaan-perusahaan utama, optimalisasi kebijakan fiskal dan lainlain (Andersen, 1997). Thomas R.Dye dalam Dunn (2000) terdapat tiga elemen kebijakan yang membentuk sistem kebijakan, dimana ketiga elemen tersebut digambarkan dengan Gambar 1.1 berikut. 
Gambar 2.1

Tiga Elemen Sistem Kebijakan

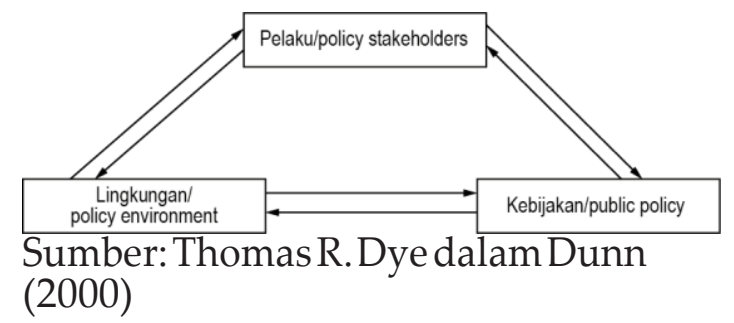

Ketiga elemen ini saling mempengaruhi, memiliki andil dan berinteraksi, sebagai contoh, pelaku kebijakan dapat mempengaruhi, memiliki andil dan berinteraksi dalam lingkungan dan kebijakan, mereka juga dapat dipengaruhi oleh kebijakan, dan lingkungan. Dunn (2000) menyatakan bahwa "Sistem kebijakan berisi proses yang dialektis, yang berarti bahwa dimensi obyektif dan subyektif dari pembuat kebijakan tidak terpisahkan didalam prakteknya".

Penerapan prinsip-prinsip good governance sangat penting dalam pelaksanaan kegiatan pemerintah untuk mewujudkan kesejahteraan dan pemerataan, hal ini disebabkan karena tujuan dilaksanakan pembangunan salah satunya adalah dengan mewujudkan perubahan dalam birokrasi yang memiliki komitmen terhadap kesejahteraan rakyat (Simatupang, 2007).

Pelaksanaan peran pemerintah tersebut salah satunya dengan pelaksanaan desentralisasi mengacu kepada teori desentralisasi, menurut Mardiasmo (2003) teori tersebut adalah symbol trust dari pemerintah pusat, untuk membebaskan pemerintah pusat dari beban-beban yang tidak perlu dalam urusan domestik, diharapkan melalui desentralisasi ini wilayah domestik tersebut mempunyai kesempatan untuk mempelajari, memahami dan merespon kecenderungan global dan mengambil manfaatnya, sehingga kemampuan prakarsa dan kreativitas mereka akan lebih terpacu. Dalam hal itu, pemerintah pusat dapat lebih berkonsentrasi pada perumusan kebijakan makro nasional yang sifatnya strategis.

Menurut penelitian (John dan George, 1996) ditemukan bahwa pengeluaran pemerintah tersebut dalam jangka panjang maupun pendek berdampak terhadap pertumbuhan ekonomi suatu negara hal tersebut juga sesuai dengan penelitian (Aschaur, 1999) dimana ditemukan bahwa modal publik berperan positif terhadap pertumbuhan ekonomi, namun dalam penelitian (Daniel J.Mitchell, 2005) ditemukan bahwa terdapat kecenderungan semakin turunnya pengeluaran pemerintah maka semakin tinggi pertumbuhan ekonomi.

\section{Definisi Pemerintahan Good Gov- ernance}

\section{Definisi Pemerintahan}

Menurut Hadjon (1982) Pengertian pemerintah dapat dilihat dari dua perspektif yaitu pemerintahan dalam arti sempit dan pemerintahan dalam arti yang luas. Pemerintah dalam arti luas dapat dikemukakan oleh beberapa ahli antara lain:

1. Mostesquieu: Pemerintah dalam arti luas menurut ajaran Trias Politica yaitu meliputi: Pembentukan Undang-Undang, Pelaksanaan, Peradilan.

2. Van Vollenhoven: Meliputi membuat peraturan, pemerintah atau pelaksana, peradilan dan polisi.

3. A.M.Donner: Mengadakan pembagian berdasarkan ilmu administrasi, pemerintahan dalam arti luas itu meliputi: Badan-badan pemerintahan di pusat yang menentukan haluan negara dan instansi-instansi yang melaksanakan keputusan badan-badan tersebut di atas.

4. Van Poelje: Hanya merupakan badanbadan pelaksanaan saja, tidak termasuk badan perundang-undangan, badan pemerintahan dan badan kepolisian sebagai organ perlengkapan $\mathrm{Ne}$ gara yang diserahi pemerintahan.

\section{Definisi Good Governance}

Konsep good governance meliputi, good governance (tata pemerintahan yang baik), good government (pemerintahan yang baik), dan clean governance (pemerintahan yang bersih). Menurut Quadrat, 2009, Prasetijo, 2009 dalam good governance terdapat tiga pilar yang penting, yaitu: kesejahteraan rakyat (economic governance), proses pengambilan keputusan (political governance) dan tata laksana pelaksanaan kebijakan (administrative governance).

Manajemen pembangunan memposisikan pemerintah dalam posisi yang penting, pemerintah dalam hal ini berfungsi sebagai agent of change (agen perubahan), agent of development (pendorong proses 
pembangunan) yang dilaksanakan melalui kebijakan - kebijakan dan program - program.

Penerapan prinsip-prinsip good governance sangat penting dalam pelaksanaan kegiatan pemerintah untuk mewujudkan kesejahteraan dan pemerataan, hal ini disebabkan karena tujuan dilaksanakan pembangunan salah satunya adalah dengan mewujudkan perubahan dalam birokrasi yang memiliki komitmen terhadap kesejahteraan rakyat (Simatupang, 2007). Menurut United National Economic and Social Commission for Asia and The Pasific (UNESCAP) (Safri Nugraha, 2005) prinsip - prinsip dalam penyelenggaran good governance yaitu: Accountable: Tanggung gugat dari pengurusan, penyelenggaraan dari governance yang dilakukan lebih jauh diartikan adalah kewajiban bagi apartur pemerintah untuk bertindak selaku penanggung jawab dan penanggung gugat atas segala tindakan dan kebijaksanan yang ditetapkan. Transparent: Dapat diketahui oleh banyak pihak mengenai perumusan kebijaksanaan (Politik) dari pemerintah, organisasi, badan usaha. Dengan kata lain, segala tindakan dankebijaksanaan pemerintah baik di pusat maupun di daerah harus selalu dilaksanakan secara terbuka diketahui oleh umum. Responsive: Lembaga-lembaga dan proses - proses harus mencoba untuk cepat tanggap untuk melayani setiap stakeholders. Equitable and inclusive: Semua warganegara, baik laki-laki maupun perempuan, mempunyai kesempatan untuk meningkatkanatau menjaga kesejahteraan mereka. Effectiveness and efficiency: Proses-proses dan lembaga-lembaga menghasilkan sesuai dengan apa yang telah digariskan dengan menggunakan sumber-sumber yang tersedia sebaik mungkin. Follow the rule of law: Kerangka hukum harus adil dan dilaksanakan tanpa pandang bulu, terutama hukum untuk hak azasi manusia. Participatory: Setiap warganegara mempunyai suara dalam pembuatan keputusan, baik secara langsung maupun melalui intermediasi institusi legitimasi yang mewakili kepentingannya. Partisipasi seperti ini dibangun atas dasar kebebasan berasosialisasi dan berbicara serta berpartisipasi secara konstruktif. Consensus orientation: Good governance menjadi perantara kepentingan yang berbeda untuk memperoleh pilihan terbaik bagi kepentingan yang luas baik dalam hal kebijakan-kebijakan maupun prosedur-prosedur.

Selama reformasi berlangsung, pemerintah telah menerbitkan beberapa aturan untuk menerapkan akuntabilitas, antara lain Inpres Nomor 7 Tahun 2009 tentang Sistem Akuntabilitas Kinerja Instansi Pemerintah (SAKIP) sampai yang terakhir adalah Permenpan Nomor 29 Tahun 2010 yang mengatur tentang penyusunan Penetapan Kinerja dan Laporan Akuntabilitas Kinerja Instansi Pemerintah. Selain hal tersebut, Menteri Pendayagunaan Aparatur Negara dan Reformasi Birokrasi (MENPAN dan RB) telah mengeluarkan undang-undang untuk mengikat instansi pemerintah agar akuntabel. Peraturan Pemerintah Nomor 8 tahun 2008 tentang tahapan, tata cara penyusunan, pengendalian, dan evaluasi pelaksanaan rencana pembangunan daerah tersebut telah mengubah sistematika penyusunan dokumen perencanaan. Peraturan Pemerintah mensyaratkan adanya sasaran, indikator kinerja serta target yang harus ditetapkan dalam RPJMD, Renstra SKPD, RKPD dan Renja SKPD, kemudian pemerintah menerbitkan Permendagri No. 54 tahun 2010 sebagai tindak lanjut pelaksanaan Peraturan Pemerintah tersebut. Permendagri Nomor 54 Tahun 2010 memberikan harapan baru penerapan Sistem Akuntabilitas Kinerja Instansi Pemerintah (SAKIP) yang lebih sempurna. Peraturan ini mengharuskan pemerintah daerah untuk menyusun dokumen perencanaan yang dapat dipertanggunjawabkan secara terukur. Dengan adanya petunjuk pelaksanaan PP Nomor 8 Tahun 2008 yang sangat detail dan jelas diharapkan dapat mendorong pemerintah daerah untuk lebih akuntabel.

Selain SAKIP tersebut, indikator pelaksanaan pemerintahan yang baik di Indonesia dapat dilihat dari Laporan Keuangan Pemerintah Daerah (LKPD) yang pemeriksaannya dilaksanakan oleh Badan Pemeriksa Keuangan (BPK). Hal tersebut sesuai dengan Pasal 23 Undang-Undang Dasar Republik Indonesia Tahun 1945 yang menyebutkan fungsi BPK sebagai lembaga negara yang bebas dan mandiri, dan melaksanakan tugas pengawasan pengelolaan keuangan negara, pemeriksaan terhadap pengelolaan dan tanggung jawab keuangan negara tersebut dilaksanakan 
untuk mendukung terwujudnya tujuan negara yang untuk mencapai masyarakat adil, makmur dan sejahtera. Undang Undang Nomor 15 Tahun 2006 tentang BPK, menyebutkan BPK mempunyai tugas dalam bidang operatif, advisory, dan yudikatif (Jimly Asshiddiqie, 2006;168) BPK telah melaksanakan praktek-praktek transparansi dan akuntabilitas untuk membangun sistem pemerintahan yang baik dan bersih, serta terwujudnya tata kelola pemerintahan yang baik (good governance).

\section{Teori Pertumbuhan Ekonomi}

Menurut Tambunan (2001) pertumbuhan ekonomi adalah penambahan Produk Domestik Bruto (PDB) yang berarti penambahan Pendapatan Nasional (PN). Pertumbuhan ekonomi merupakan suatu proses peningkatan kapasitas produksi dari perekonomian secara komprehensif dan terus menerus atau berkesinambungan sepanjang waktu, sehingga menghasilkan tingkat pendapatan nasional yang semakin lama semakin besar (Todaro, 2000). Pertumbuhan ekonomi suatu negara sebagai kenaikan kapasitas jangka panjang untuk menyediakan ekonomi pada penduduk. Pertumbuhan ekonomi menurut Suparmoko (1998) merupakan salah satu tujuan penting dari kebijakan ekonomi makro yang berkaitan ukuran fisik berupa peningkatan produksi barang dan jasa.

Berdasarkan pengertian di atas, pertumbuhan ekonomi memiliki tiga aspek penting yaitu pertumbuhan sebagai proses dan bukan suatu deskripsi di waktu tertentu, berkaitan dengan tingkat pendapatan nasional, dan mengandung aspek perspektif waktu jangka panjang.

Peningkatan belanja pegawai diharapkan akan menyebabkan kenaikan produksi yang diukur dengan PDB dan PDRB serta kenaikan belanja barang dan jasa diharapkan memberikan dampak positif terhadap peningkatan produksi nasional dan provinsi. Peningkatan belanja barang dan jasa juga akan mendorong penyerapan tenaga kerja di masing-masing sektor.

\section{Faktor-Faktor Yang Mempengaru- hi Pertumbuhan Ekonomi \\ 1. Faktor Internal}

Lambatnya proses pemulihan ekonomi nasional lebih disebabkan kondisi politik, sosial, dan keamanan di dalam negeri. Pemulihan ekonomi Indonesia berjalan lambat karena proses perbaikan ekonomi nasional tidak disertai kestabilan politik dan keamanan yang memadai, penyelesaian konflik sosial, serta kepastian hukum (Tambunan, 2001).

\section{Faktor Eksternal}

Kondisi perdagangan dan perekonomian regional atau perekonomian dunia merupakan faktor eksternal yang sangat penting untuk mendukung pemulihan ekonomi Indonesia. Kondisi ini sangat berpengaruh terhadap prospek pertumbuhan ekspor dan investasi asing dalam negeri.

Menurut Todaro (2003), Pertumbuhan ekonomi dipengaruhi oleh beberapa faktor, yaitu: Pertumbuhan Penduduk dan Angkatan Kerja, Akumulasi Modal, Kemajuan Teknologi.

\section{Posisi Pertumbuhan Ekonomi da- lam Kesejahteraan Masyarakat}

Pertumbuhan ekonomi merupakan indikator yang sangat penting dalam melihat kemajuan pembangunan ekonomi di suatu daerah. Pertumbuhan ekonomi menunjukkan sejauh mana aktivitas perekonomian akan menghasilkan tambahan pendapatan masyarakat pada suatu periode tertentu (Susanti, 2007). World Bank (2007) mengemukakan bahwa pertumbuhan ekonomi adalah satu-satunya penggerak terpenting bagi upaya penanggulangan kemiskinan. Karena itu, upaya menjadikan pertumbuhan ekonomi bermanfaat bagi penduduk miskin membutuhkan upaya menciptakan pertumbuhan sekaligus memastikan bahwa pertumbuhan ini dapat dirasakan oleh penduduk miskin.

Secara singkat alur posisi dari pertumbuhan ekonomi tersebut dapat ditunjukkan dalam gambar 4.1 berikut. 
Gambaf 4.1

Pertumbuhan Ekonomi dalam Kesejahteraan Masyarakat

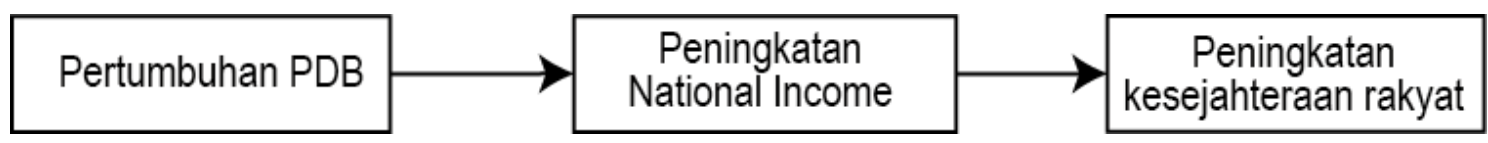

Sumber: Todaro, 2002

\section{BAB III \\ PERAN DAN FUNGSI PEMERINTA- HAN GOOD GOVERNANCE DALAM MEWUJUDKAN PERTUMBUHAN EKONOMI}

\section{Peran dan Hubungan Pemerin- tahan Good Governance dan Per- tumbuhan Ekonomi di Provinsi Bali}

Menurut Mardiasmo (2002), Government Governance dapat diartikan sebagai cara mengelola urusan-urusan publik, World Bank lebih menekankan pada cara pemerintah mengelola sumber daya sosial dan ekonomi untuk kepentingan pembangunan masyarakat, sedangkan United National Development Program (UNDP) lebih menekankan

Penerapan prinsip-prinsip Good Government Governance tersebut pada dasarnya juga ditujukan untuk pengelolaan organisasi supaya lebih baik dan pada akhirnya akan mendukung ketercapaian kinerja organisasi seperti yang diharapkan oleh stakeholder. Dalam penerapannya Good Government Governance dikenal dengan adanya lima prinsip utama, kelima prinsip tersebut adalah transparansi, akuntabilitas, pertanggungjawaban, independensi, dan keadilan. Uraian dari masing-masing prinsip adalah transparansi, akuntabilitas, pertanggungjawaban, independensi, dan keadilan (Indonesia Institute of Corporate Governance (IICG).

Pemerintah daerah meliputi kepala daerah beserta perangkatnya meliputi badan, dinas, kantor dan unit pelaksana teknis dimana masing-masing merupakan SKPD yang memiliki fungsi dalam pelayanan publik. Larry D Stout (1993) dalam Indra (2001) menyatakan bahwa: "Pengukuran/penilaian kinerja merupakan proses mencatat dan mengukur pencapaian pelaksanaan kegiatan dalam arah pencapaian misi (mission accomplishment) melalui hasil-hasil yang ditampilkan berupa produk, jasa, ataupun suatu proses". Menurut James B. Whittaker (1993) dalam Indra (2001) menyatakan bahwa: "Pengukuran/penilaian kinerja adalah suatu alat manajemen untuk meningkatkan kualitas pengambilan keputusan dan akuntabilitas."

Dalam penerapannya, dibutuhkansuatu artikulasi yang jelas mengenai visi, misi, tujuan, dan sasaran yang dapat diukur dari suatu dan keseluruhan program. Ukuran tersebut bisa dikaitkan dengan hasil atau outcome dari setiap program yang dilaksanakan. Dengan demikian, pengukuran kinerja organisasi merupakan dasar yang reasonable (pantas) untuk pengambilan keputusan. Pengukuran kinerja organisasi dikelompokkan menjadi dua, yaitu pengukuran kinerja non keuangan (non financial) dan pengukuran kinerja keuangan (financial), (Morse dan Davis, 1996 dalam Anita, 2002).

Negara maju dimana tingkat korupsinya rendah, peran pemerintah dalam perekonomian hanya sebatas pembuat kebijakan dan peraturan namun tetap mengawasi secara sungguh-sungguh jalannya pelaksanaan kebijakan dan peraturan tersebut dengan harapan peran swasta dapat berjalan secara optimal. Kecenderungan korupsi sejalan dengan peringkat indikator "control of corruptionz”, (Kaufmann,2000). Negara-negara yang korupsinya tinggi cenderung memiliki "control of corruption" yang rendah dan sebaliknya.

Menurut Mangkusoebroto (1999) kegagalan pemerintah disebabkan oleh empat hal, yaitu :.

1. Informasi yang terbatas, diungkapkan bahwa banyak kebijakan pemerintah yang tidak dapat dilihat dampaknyakarena sangat rumit dan sulit untuk diperhitungkan sebelumnya. Misalnya, kebijakan pemerintah untuk menghapuskan subsidi pupuk bagi petani sangat sulit untuk diperhitungkan secara akurat dampaknya bagi seluruh masyarakat. 
2. Pengawasan yang terbatas atas reaksi swasta juga merupakan penyebab kegagalan pemerintah. Suatu kebijakan pemerintah akan menimbulakn reaksi pihak swasta dan sering sekali pemerintah tidak dapat menghambat reaksi tersebut. Misalnya, apabila pemerintah menurunkan subsidi BBM khususnya untuk bensin. Hal ini akan menyebabkan pemilik mobil beralih kepemilikan kendaraan yang menggunakan solar sehingga permintaan akan solar menjadi meningkat dan harganya naik. Dalam hal ini karena pertimbangan untuk memiliki mobil sepenuhnya berada pada swasta/masyarakat maka pemerintah tidak dapat melarang seseorang untuk menjual mobil yang menggunakan bensin ke mobil yang menggunakan solar.

3. Kegagalan pemerintah juga disebabkan oleh pengawasan yang terbatas atas perilaku birokrat. Pemerintah tidak dapat mengawasi secara ketat perilaku para birokrat, sedangkan pelaksan- aan kebijakan pemerintah umumnya didelegasikan pada berbagai tingkatan birokrat yang mempunyai persepsi dan kepentingan yang berbeda-beda, sehingga kebijakan pemerintah mungkin menimbulkan hasil yang berbeda dengan apa yang dinginkan.

4. Selain itu, kegagalan pemerintah juga bisa di sebabkan oleh adanya hambatan dalam proses politik. Dalam suatu negara demokratis terdapat pemisahan wewenang antara kekuasaan eksekutif dan kekuasaan legislatif.

Sering terjadi kebijakan yang akan dilaksanakan oleh eksekutif terhambat oleh proses pengambilan keputusan karena harus disetujui dahulu oleh pihak legislative Weimer dan Vining (1992) menyebutkan bahwa kegagalan pemerintah merupakan persoalan yang inheren dalam empat sosok sistem politik : demokrasi langsung, representative government, bureaucratic supply, dan pemerintahan yang terdesentralisasi.

Tabel 3.1

Ringkasan Sumber-Sumber Kegagalan Pemerintah

\begin{tabular}{|c|c|}
\hline Direct democracy & $\begin{array}{l}\text { 1. Paradox of voting (meaning of mandate is } \\
\text { ambiguous) } \\
\text { 2. Preference intensity and bundling ( minorities bear } \\
\text { costs of inefficient social choices ) }\end{array}$ \\
\hline $\begin{array}{l}\text { Representative } \\
\text { government }\end{array}$ & $\begin{array}{l}\text { 1. Influence of organized interests ( rent seeking ) } \\
\text { 2. Geographic constituencies ( pork-barrel allocation ) } \\
\text { 3. Limited time horizon induced by electoral cycle } \\
\text { (underinvesment ) } \\
\text { 4. Posturing to public attention ( restrictive agendas ) }\end{array}$ \\
\hline $\begin{array}{l}\text { Bureaucratic } \\
\text { supply }\end{array}$ & $\begin{array}{l}\text { 1. Agency problem ( diversion of resources ) } \\
\text { 2. Difficulty valuing output ( X-efficiency ) } \\
\text { 3. Limited competition ( X-efficiency ) } \\
\text { 4. Civil services protection ( inflexibility ) } \\
\text { 5. Bureau failure as market failure ( allocative and X- } \\
\text { efficiency) }\end{array}$ \\
\hline Decentralization & $\begin{array}{l}\text { 1. Diffuse authority ( implementation problems) } \\
\text { 2. Fiscal externalities (unequal distribution of local } \\
\text { public goods) }\end{array}$ \\
\hline
\end{tabular}

Sumber: Weimer dan Vinning, 1992 
Agar kesejahteraan manusia dapat ditingkatkan, terlebih dahulu harus meningkatkan kapabilitas pemerintah. Kapabilitas disini didefinisikan sebagai kemampuan untuk membentuk dan mendorong tindakan kolektif secara efisien (World Bank, 1997), yang kemudian diterjemahkan dalam dua strategi besar yang satu sama lain saling berkaitan :

1. Menyesuaikan peran pemerintah dengan kapabilitasnya

2. Meningkatkan kapabilitas pemerintah dengan cara membangun dan mengiatkan kelembagaan bagi sektor publik.

Konsep negara kesejahteraan menekankan kepada peran pemerintah yang responsif dalam mengorganisasikan dan mengelola perekonomian sehingga mampu melaksanakan tanggungjawabnya guna menjamin ketersediaan pelayanan kesejahteraan dasar dalam tingkat tertentu bagi warganya (Andersen, 1997).

Teori yang menguatkan mengenai pentingnya peranan pemerintah dalam meningkatkan kesejahteraan masyarakat adalah Teori Kepentingan Publik (Public Interst Theory) yang dikemukakan oleh Posner (1974), bahwa teori ini meman- dang bahwa regulasi seharusnya meningkatkan kemakmuran sosial, teori ini berusaha menunjukkan bahwa regulasi yang ditetapkan merupakan hasil dari tuntutan publik dari hasil koreksi atas kegagalan pasar. Dari pendapat diatas dapat disimpulkan bahwa peranan pemerintah sangat strategis dalam proses pembuatan kebijakan untuk mengatur belanja publik guna meningkatkan kesejahteraan masyarakat secara menyeluruh. Kaitannya dengan peranan pemerintah dalam membuat kebijakan untuk kesejahteraan masyarakat, menurut Thomas R.Dye dalam Dunn (2000) terdapat tiga elemen kebijakan yang membentuk sistem kebijakan.

Sinergitas antara pemerintah dan prinsip good governance mutlak diperlukan dalam pelaksanaan setiap kebijakan yang telah dihasilkan, pelaksanaan good governance tersebut berpengaruh terhadap pembangunan manusia dan penurunan tingkat kemiskinan (David Sebudubudu, 2010) dimana pada akhirnya akan bermuara kepada kesejahteraan masyarakat. Hal tersebut diperkuat oleh pendapat (Rodrik et all, 2003) bahwa peranan Institusi (pemerintah), perdagangan, dan geografis berpengaruh terhadap pertumbuhan ekonomi.

Gambar 3.1 Teori“Deep Determinants” of Income

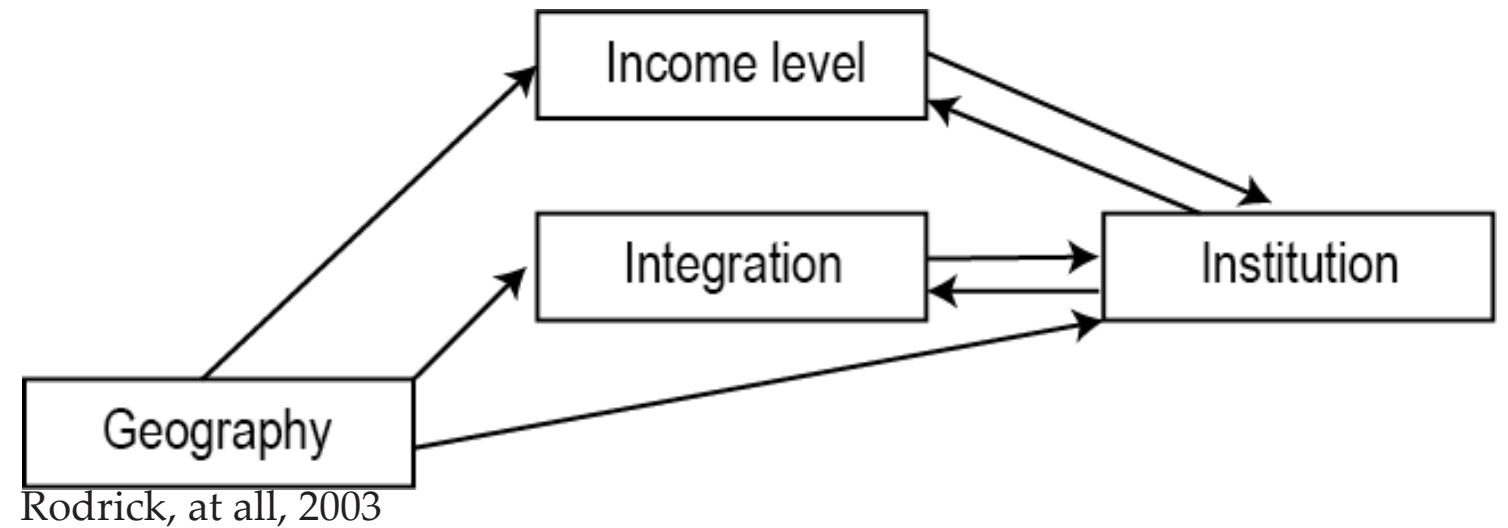

Berdasarkan Gambar 3.1 di atas komponen geography adalah presentasi dari kondisi lingkungan suatu institusi, komponen Institution merupakan presentasi dari institusi/lembaga yang menerapkan hak kepemilikan dan penegakan hukum, sedangkan komponen Integration adalah pelaksanaan kegiatan ekonomi. Komponen geography memberikan pengaruh paling banyak terhadap Integration, Insti- tution, dan Income level. (Rodrik et all, 2003). Bahwa dalam hal ini dapat diasumsikan bahwa faktor lingkungan sebagai good governance, yang mempengaruhi kondisi suatu lembaga dimana dalam pelaksanaan kegiatan lembaga tersebut diintegrasikan oleh pelaksanaan kegiatan ekonomi sehingga berdampak terhadap tingkat pendapatan.

Hal tersebut merupakan wujud dari 
teori desentralisasi, menurut Mardiasmo (2003) teori tersebut adalah symbol trust dari pemerintah pusat, untuk membebaskan pemerintah pusat dari beban-beban yang tidak perlu dalam urusan domestik, diharapkan melalui desentralisasi ini wilayah domestik tersebut mempunyai kesempatan untuk mempelajari, memahami dan merespon kecenderungan global dan mengambil manfaatnya, sehingga kemampuan prakarsa dan kreativitas mereka akan lebih terpacu. Dalam hal itu, pemerintah pusat dapat lebih berkonsentrasi pada perumusan kebijakan makro nasional yang sifatnya strategis.

\section{Fungsi Pemerintahan Good Govern- ance Dalam Mewujudkan Pertumbu- han Ekonomi}

Fungsi pemerintah dalam ekonomi modern secara umum adalah sebagai lem-

baga yang melaksanakan peran alokasi, distribusi, dan stabilitas. Seperti penjelasan diatas, secara umum peran pemerintah secara umum tersirat dalam konsep negara kesejahteraan menekankan kepada peran pemerintah yang responsif dalam mengorganisasikan dan mengelola perekonomian sehingga mampu melaksanakan tanggungjawabnya guna menjamin ketersediaan pelayanan kesejahteraan dasar dalam tingkat tertentu bagi warganya (Andersen, 1997).

Todaro (1997) menyebutkan bahwa pemerintah harus diakui dan dipercaya untuk memikul peranan lebih besar dan yang lebih menentukan di dalam upaya pengelolaan perekonomian daerah/nasional. Pembangunan ekonomi tidak dapat dilepaskan dari peranan pemerintah dalam menciptakan suatu kondisi yang dapat mendukung elemen-elemen dalam pertumbuhan ekonomi dan kesejahteraan yang dapat dicapai suatu daerah. Beberapa upaya pemerintah tersebut ditempuh antara lain dengan berbagai regulasi, nasionalisasi perusahaan-perusahaan utama, optimalisasi kebijakan fiskal dan lain-lain (Andersen, 1997).

Dalam rangka mewujudkan kesejahteraan bagi masyarakat, pemerintah membentuk suatu kebijakan publik, menurut James A. Anderson dalam Subarsono (2005), Kebijakan publik merupakan kebijakan yang ditetapkan oleh badan-badan pemerintah. Hal tersebut juga diperkuat oleh Laswell dan Kaplan, David Easton (Subarsono,
2005) mendefinisikan kebijakan publik sebagai pengalokasian nilai-nilai kepada masyarakat karena setiap kebijakan mengandung seperangkat nilai di dalamnya. Beberapa hasil penelitian yang dapat dijadikan acuan antara lain:

1. Estache (2007) dalam penelitiannya yang menemukan Hubungan negatif yang kuat antara ukuran pemerintah dan pertumbuhan ekonomi. Namun hubungan negatif tersebut hanya dapat diterapkan untuk Negara kaya dengan sektor publik yang luas. Sedangkan Negara sedang berkembang lebih berorientasi mengembangkan ukuran pemerintah untuk perlindungan hak kepemilikan dan mengadakan hubungan kerjasama dengan Negara lain.

2. Abu-Daber \& Aamer (2003) menemukan bahwa pengeluaran militer berpengaruh negatif terhadap pertumbuhan ekonomi sementara pengeluaran sipil berpengaruh positif terhadap pertumbuhan ekonomi di Israel dan Mesir. Hasil yang agak berbeda ditemukan oleh Sodik (2007) yang menemukan bahwa variabel investasi swasta tidak berpengaruh terhadap pertumbuhan ekonomi regional. Variabel keterbukaan ekonomi memiliki hubungan yang konsisten dengan teori tetapi tidak signifikan variable angkatan kerja berpengaruh signifikan dengan tanda negatif untuk tahun 1993-2003 dan tahun 1998-2000.

3. Menurut Penelitian Harry (2013) tentang pengaruh pengeluaran pemerintah terhadap PDRB, ditemukan dalam penelitian ini bahwa pengeluaran pemerintah pada sektor pertanian, perikanan, serta perindustrian dan perdagangan berpengaruh terhadap PDRB.

4. Pascual dan Álvarez-García (2006) meneliti pengeluaran pemerintah dan pertumbuhan ekonomi di negara Eropa mengambil kesimpulan bahwa hubungan antara pengeluaran pemerintah pertumbuhan ekonomi dan pengeluaran pemerintah dapat positif atau negatif tergantung dari negara yang menjadi sampel penelitian. Seperti halnya penelitian ini yang menganalisis pengaruh pengeluaran pemerintah terhadap pertumbuhan ekonomi. 
HASIL PENELITIAN DAN PEMBAHASAN

Metode analisis yang digunakan dalam penelitian ini adalah dengan melihat perbandingan antara Pertumbuhan Pengeluaran Konsumsi Pemerintah terhadap Pertumbuhan PDRB, penulis menganalisa data tersebut dengan menggunakan regresi linier sederhana, dengan persamaan matematis yang digunakan adalah:

$\mathrm{Y}=\mathrm{a}+\mathrm{bx}$

\author{
Keterangan: \\ Y : PDRB \\ a : Konstanta Regresi \\ bx : Nilai turunan atau peningkatan vari- \\ abel bebas \\ Y : PDRB \\ a : Konstanta Regresi \\ bx: Nilai turunan atau peningkatan vari- \\ abel
}

\section{Grafik 3.1}

Laju Pertumbuhan PDRB Menurut Penggunaan (Pengeluaran Konsumsi Pemerintah) Atas Dasar Harga Konstan Tahun 1998-2014

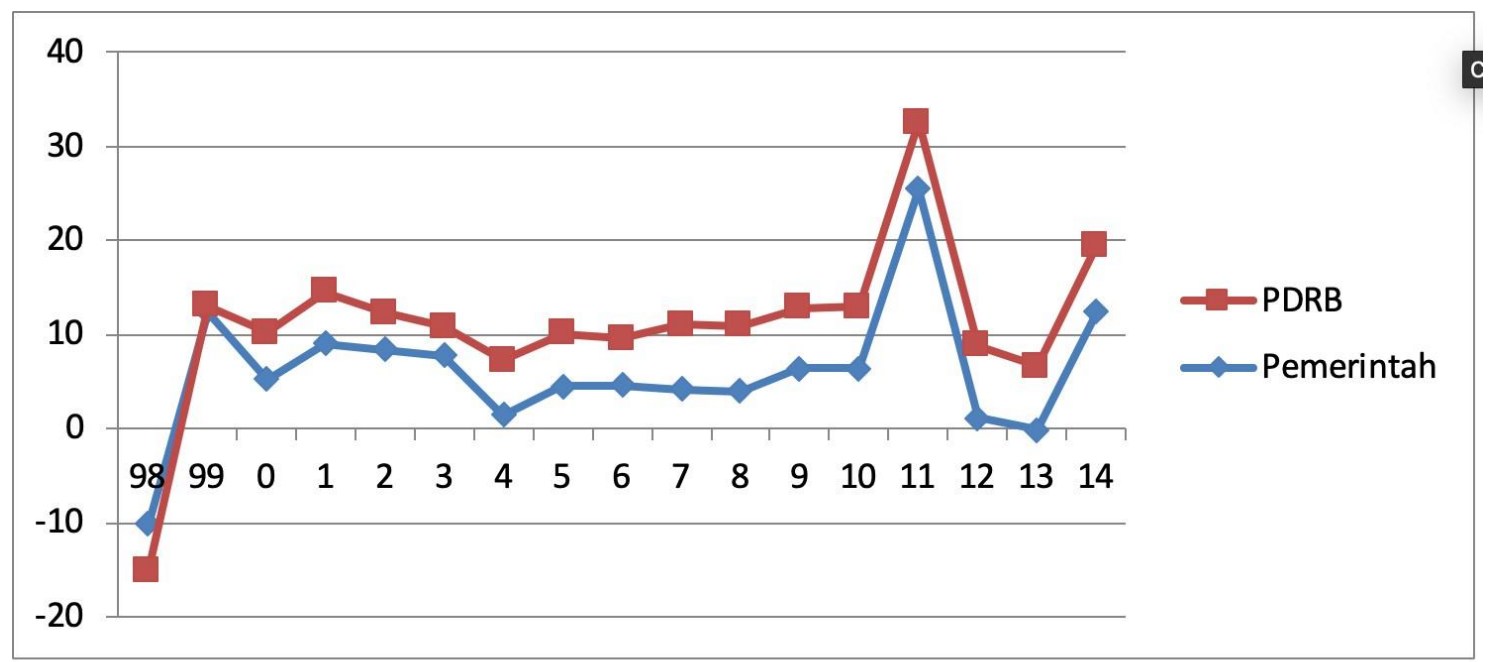

\section{Sumber: BPS Kabupaten Badung, 2015}

Untuk lebih dalam mengetahui adakah pengaruh yang nyata Pertumbuhan Pengeluaran Konsumsi Pemerintah terhadap Pertumbuhan PDRB, penulis menganalisa data tersebut dengan menggunakan regresi linier sederhana, dengan persamaan matematis yang digunakan adalah:

$\mathrm{Y}=\mathrm{a}+\mathrm{bx}$

Keterangan:

Y : PDRB

a : Konstanta regresu

bx : Nilai turunan atau peningkatan variabel bebas.

Data yang telah dianalisis menggunakan SPSS diperoleh hasil sebagai berikut:

1. Pengaruh Pertumbuhan Konsumsi Pemerintah terhadap PDRB adalah sebesar $16,5 \%$ sedangkan sisanya dipengaruhi oleh variable yang lain;

2. Diperoleh bahwa jika tidak ada nilai Pertumbuhan Konsumsi Pemerin- tah maka nilai Pertumbuhan PDRB sebesar 3,911. dan setiap penambahan 1 nilai Pertumbuhan Konsumsi Pemerintah, maka nilai Pertumbuhan PDRB akan bertambah sebesar 0,175 .

3. Karena nilai t hitung yang diperoleh sebesar 1,721 dengan nilai signifikansi maka 0,106>0.05 maka Pertumbuhan Konsumsi Pemerintah berpengaruh tidak signifikan terhadap Pertumbuhan PDRB.

Untuk memperkuat hasil analisis data diatas penulis juga melakukan interpretasi terhadap tingkat data pelaksanaan penerapan good governance, pertumbuhan ekonomi dan kesejahteraan masyarakat salah satu pemerintah daerah di Provinsi Bali dalam hal ini Pemerintah Kabupaten Badung. 
JURNAL CAKRAWARTI, Vol. 03 No. 02, Ags '20 - Jan '21

DATA PELAKSANAAN GOOD GOVERNANCE, PERTUMBUHAN EKONOMI

DAN KESEJAHTERAAN, MASYARAKAT DI KABUPATEN BADUNG

\begin{tabular}{|l|c|c|c|c|c|c|c|c|}
\hline \multicolumn{1}{|c|}{ JENIS DATA } & $\mathbf{2 0 0 8}$ & $\mathbf{2 0 0 9}$ & $\mathbf{2 0 1 0}$ & $\mathbf{2 0 1 1}$ & $\mathbf{2 0 1 2}$ & $\mathbf{2 0 1 3}$ & $\mathbf{2 0 1 4}$ & $\mathbf{2 0 1 5}$ \\
\hline LHP & 1,00 & 3 & 3 & 4 & 4 & 1 & 4 & 4,00 \\
\hline LAKIP & 35,45 & 35,72 & 34,27 & 55,31 & 65,92 & 69,12 & 75,89 & 76,37 \\
\hline $\begin{array}{l}\text { PERTUMBUHAN } \\
\text { EKONOMI }\end{array}$ & 6,91 & 6,39 & 6,48 & 7,07 & 7,64 & 6,82 & 6,97 & 6,27 \\
\hline $\begin{array}{l}\text { KESEJAHTERAAN } \\
\text { MASYARAKAT (IPM) }\end{array}$ & 74,12 & 74,49 & 75,84 & 76,66 & 77,26 & 77,63 & 77,98 & 78,86 \\
\hline
\end{tabular}

Sumber: dari berbagai sumber 2016.

Dari interpretasi data diatas dapat disimpulkan dan dianalogikan secara sederhana bahwa dengan naiknya tingkat penerapan good governance di Kabupaten Badung yang ditunjukkan dengan nilai Laporan Hasil Pemeriksaan, dan nilai Laporan Kinerja Instansi Pemerintah (LAKIP) akan diikuti juga oleh kenaikan tingkat pertumbuhan ekonomi dan kesejahteraan masyarakat yang diwujudkan dengan nilai Indeks Pembangunan Manusia (IPM).

Dari penjelasan dan hasil penelitian yang telah dipaparkan diatas, peranan pemerintah terhadap pertumbuhan ekonomi sangat penting. Pelaksanaan peran dan fungsi pemerintah tersebut agar dapat berjalan efektif dan maksimal harus dilaksanakan dengan penerapan kebijakan good governance. Penelitian Hermanson (2003), mengenai hubungan antara penerapan good government governance dengan kinerja organisasi menyatakan bahwapenerapan good government governance berasosiasi dengan kinerja organisasi. Suatu organisasi akan sangat terbantu kinerjanya apabila dalam organisasi tersebut menerapkan good government governance, begitu juga dalam pemerintahan apabila good government governance-nya bagus maka kinerjanya juga akan bagus, dan hal itu akan membuat output yang dihasilkan juga akan bagus. Hal tersebut menunjukkan bahwa kewajiban penerapan good government governance merupakan suatu hal yang tepat.dalam suatu pemerintah. Pelaksanaan kebijakan publik untuk menciptakan kesejahteraan mutlak memerlu- kan dukungan anggaran, kebijakan pengalokasian anggaran yang mendukung pelaksanaan good governance merupakan faktor penentu dalam melaksanakan pemerintahan yang baik guna mewujudkan kesejahteraan masyarakat, (Ben-Caleb, 2012) menemukan bahwa terdapat hubungan antara good governance dan penganggaran yang baik, penganggaran yang baik tanpa good governance adalah tidak mungkin karena salah satu tujuan dilaksanakannya good governance adalah untuk menciptakan penganggaran yang baik. Good governance tersebut dapat diibaratkan sebagai panduan dan pengawas dalam setiap pelaksanaan fungsi dan peran dari pemerintah tersebut melalui 8 prinsip pokoknya antara lain: akuntabel, transparan, responsive, cukup dan menyeluruh, efektif dan efisien, patuh terhadap hukum, partisipasi, berorientasi kepada kepentingan bersama. Perwujudan dari pelaksanaan good governance dalam pemerintahan adalah laporan kinerja instansi pemerintah (LAKIP) dan Laporan Keuangan Pemerintah Daerah (LKPD).

\section{BAB IV \\ PENUTUP}

\section{Simpulan}

1. Pelaksanaan good governance di Provinsi Bali semakin baik, ditunjukkan dengan pencapaian nilai LAKIP dan LKPD Provinsi Bali, kabupaten/ kota se-Bali yang semakin meningkat dari tahun ke tahun. Hal tersebut berpengaruh terhadap kondisi pere- 
konomian di Provinsi Bali dari tahun ke tahun telah mengalami perkembangan yang baik, hal tersebut dapat diamati dalam komponen pertumbuhan ekonomi yang semakin tinggi, jumlah penduduk miskin dan tingkat ketimpangan semakin berkurang.

2. Berdasarkan hasil studi dan kondisi dilapangan pelaksanaan good governance di Pemerintah Kabupaten di Wilayah Provinsi Bali mempunyai peranan yang sangat penting dalam proses peningkatan pertumbuhan ekonomi yang bermuara kepada kesejahteraan masyarakat.

\section{Saran}

Sejumlah saran yang dapat disampaikan berkaitan dengan pembahasan yang telah disampaikan, adalah sebagai berikut.

1. Diperlukan studi lanjutan berkaitan dengan semakin meningkatnya nilai good governance oleh pemerintah dikaitkan dengan implikasinya terhadap pertumbuhan ekonomi dan kesejahteraan masyarakat.

2. Bahwa good governance diperlukan untuk mendukung penerapan kebijakan-kebijakan pemerintah yang berorientasi kepada peningkatan indikator pertumbuhan ekonomi dan kesejahteraan masyarakat agar lebih efektif dan dapat berdampak secara komprehensif sesuai dengan tujuannya masing-masing.

3. Pemerintah Provinsi sebagai wakil pemerintah pusat di daerah kiranya dapat memberikan stimulus kepada pemerintah Kabupaten/Kota yang telah menerapkan good governance dalam pelaksanaan pemerintahan dengan baik, sehingga diharapkan dapat semakin mendorong peningkatan pertumbuhan ekonomi dan kesejahteraan masyarakat.

4. Pemerintah Daerah di Lingkungan Provinsi Bali kiranya dapat semakin meningkatkan inovasinya dalam menerapkan good governance dalam pelaksanaan tugas pokok dan fungsinya, antara lain dengan melibatkan unsur Informasi Teknologi (IT) sehingga dapat lebih memaksimalkan penerapan aspek-aspek good governance dalam setiap kegiatan pembangunan, pelayanan dan pemerintahan.

\section{DAFTAR PUSTAKA}

Abu-Dabe, S. \& Aamer S. (2003) Government Expenditure, Military Spending and Economic Growth : Causality Evidence from Egypt, Israel and Syria.

Boediono, 1999. Teori Pertumbuhan Ekonomis seri sinopsis, Edisi Pertama, Cetakan keenam, BPFE, Yogyakarta.

BPS, 2015, Provinsi Bali Dalam Angka, Denpasar.

Caleb, Ben dan Godwyns Ade, Good Budgeting And Good Governance: A Comparative Discourse, Departemen of Accounting, School of business, 2012, IV Year. No.2(9).

Dian Puji N. Simatupang. Kebijakan Anggaran Negara Sebagai Perwujudan Kedaulatan Rakyat. Dalam Modul: Hukum Anggaran Negara, (Jakarta: Fakultas Hukum Universitas Indonesia, 2007)

Dye, Thomas R. 1995. Undestanding Public Policy, New Jersey : Prentice Hall, Inc

Estache, A., et.al. (2007) "Growth Effects of Public Expenditure on the State and Local Level: Evidence From a Sample of Rich Government". World Bank Policy Research Working Paper 4219.

Kaufman, Daniel, Aart Kraay and Pablo Zaido-Lobaton. 2000. Governance Matters:from Measurement to Action, Finance and Development.

Kurniawan, A.L. (2008) "Analisis Pengaruh Pengeluaran Pemerintah terhadap Pertumbuhan Produk Domestik Regional Bruto Kabupaten Ponorogo Tahun 1993-2006". Skirpisi Unair, Tidak Dipublikasikan.

Mangkoesoebroto, Guritno. 1998. Ekonomi Publik, BPFE, Edisi 3, Yogyakarta.

Mardiasmo, 2002, "Otonomi dan Manajemen Keuangan Daerah”. Penerbit ANDI, Yogyakarta.

Ndraha, Taliziduhu. 1997. Metodologi Ilmu Pemerintahan, Jakarta : Rineka Cipta

Osborne, David dan Ted Gaebler, 1996. 
Mewirausahakan Birokrasi, Penerjemah Abdul Rasyid, Pustaka Binaman Presindo, Jakarta

Pascual, M. \& Álvarez-García, S. (2006) Government Spending And Economic Growth In The European Union Countries: An empirical Approach.

Rasyid, 2000. Makna Pemerintahan, Jakarta: Yarsif Watampone.

Rodrick, Dani, Arvind Subramanian, and Francesco Trebbi. 2004. Institutions rule: The primacy of institutions over geography and integration in economic development. Journal of Economic Growth 9 (2): 131-165.

Santoso, Pandji. Administrasi Publik: Teori Dan Aplikasi Good Governance. Bandung. PT.Refika Aditama, 2008; 130.

Soekanto, Soerjono. 2006. Sosiologi Suatu Pengantar.Jakarta: Raja Grafindo Persada.

Subarsono, AG.2005. Analisis Kebijakan Publik, Konsep, Teori dan Aplikasi. Pustaka Pelajar, Yogyakarta.

Tambunan, Tulus T.H. 2001. Perekonomian Indonesia Teori dan Temuan Empiris. Jakarta: Ghalia Indonesia.

Thoha, Miftah. 1991. Perspektif Perilaku Birokrasi, Jakarta : Rajawali.
Todaro M.P dan Smith Stephen C., 2012, Economic Development, Eleventh Edition, Adisson Wesley.

Todaro, M. P.2009. Pembangunan Ekonomi. Jakarta:Erlangga

Todaro, M.P and S.C.Smith. 2006. Economic Development, 8 edition. United Kingdom: Pearson Addison Weasley.

Todaro, M.P. 1997. Pembangunan Ekonomi di Dunia Ketiga, terjemahan, cetakan keempat, Jakarta, Ghalia, Indonesia.

Todaro, M.P. and Smith Stephen C. 2003, Economic Development, Eight Edition, United Kingdom: Pearson Education Limited.

UNESCAP, What is Good Governance?, http://www.unescap.org/pdd/prs/ Project Activities/Ongoing/gg/governance.asp.

Weimer, David L, and Aidan R. Vinning. 1992. Policy Analysis Concepts and Practice. Prentice Hall, New Jersey.

World Bank. 1997. World Development Report. Oxford University Press, New York.

World Bank. 1999. World Development Report. Oxford University Press, New York. 